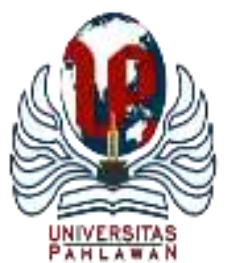

Edukatif : Jurnal Ilmu Pendidikan Volume 4 Nomor 1 Tahun 2022 Halm 7 - 18 EDUKATIF: JURNAL ILMU PENDIDIKAN

Research \& Learning in Education

https://edukatif.org/index.php/edukatif/index

\title{
Desain Pembelajaran Adaftif Berbasis Vicon melalui Model Radec bagi Peserta Didik yang Kesulitan Belajar Selama Pandemi Covid-19
}

\author{
Fachruddiansyah Muslim $^{1 凶}$, Iwan Putra $^{2}$, Ahmad Nasori $^{3}$ \\ Universitas Jambi, Indonesia ${ }^{1,2,3}$ \\ E-mail : fachruddiansyah.muslim@unja.ac.id ${ }^{1}, \underline{\text { iwanputra@ unja.ac.id }}^{2},{\underline{\text { nasoriunja@ } \text { gmail.com }^{3}}}^{3}$
}

\begin{abstract}
Abstrak
Pengembangan riset penelitian ini didasari pada studi empirical awal peneliti selama masa Pandemi Covid 19 menemukan beragam masalah terkait dengan kurangnya kemauan mahasiswa dalam membaca buku apalagi pembelajaran tidak dilakukan secara tatap muka, sehingga harus diperlukan alternatif lain dalam menumbuhkan keinginan mahasiswa salah satu diantaranya dengan mengakomodasi kebutuhan belajar mahasiswa menggunakan fasilitas Vicon yang terintegrasi melalui pembelajaran adaftif. Penelitian ini dilakukan dengan tujuan sebagai bentuk penguatan kemitraan antara dosen dengan mahasiswa, terutama pada aspek pengalaman belajar menggunakan basis teknologi melaui desain Pembelajaran Adaftif Berbasis Vicon melalui Model RADEC bagi Peserta Didik yang Kesulitan Belajar. Didalam mendesain pembelajaran adaftif dalam penelitian ini jenis pengembangan model yang digunakan berasal dari Borg \& Gall, melalui asimilasi model Dick \& Carey dari bentuk desain model multimedia, serta model Alessi \& Trollip melalui penggunaan sintaks model mengembangkan dan evaluasi terkait multimedia. Produk media pembelajaran interaktif berbasis vicon yang dihasilkan valid, praktis dan efektif berdasarkan validasi yang dilakukan oleh ahli media, peserta didik dan tenaga kependidikan. Ini ditunjukkan melalui kemudahan peserta didik dalam memperoleh kebutuhan materi pembelajaran melalui media pembelajaran yang dikembangkan. Pola desain yang dirancang dalam penelitian ini mampu memberi ruang berfikir kepada mahasiswa dalam memberikan pengalaman belajar mengajar untuk kepentingan peningkatan kualitas pembelajaran.
\end{abstract}

Kata Kunci: Desain Pembelajaran, Model Pembelajaran, Kesulitan Pembelajaran.

\begin{abstract}
The development of this research research is based on the initial empirical study of researchers during the Covid-19 pandemic, which found various problems related to the lack of students' willingness to read books, especially when learning is not done face-to-face, so other alternatives must be needed to foster student desires, one of which is by accommodating learning needs. students use the integrated Vicon facility through adaptive learning. This research was conducted with the aim of strengthening the partnership between lecturers and students, especially in the aspect of learning experiences using technology based through the design of Vicon-Based Adaptive Learning Through the RADEC Model for Students with Learning Difficulties. In designing adaptive learning in this research, the type of model development used comes from Borg \& Gall, through the assimilation of the Dick \& Carey model from the form of multimedia model design, and the Alessi \& Trollip model through the use of the syntax of developing and evaluating models related to multimedia. The resulting vicon-based interactive learning media products are valid, practical and effective based on the validation carried out by media experts, students and education staff. This is shown through the ease of students in obtaining the needs of learning materials through the developed learning media. The design pattern designed in this study is able to give students space to think in providing teaching and learning experiences for the benefit of improving the quality of learning.
\end{abstract}

Keywords: Learning Design, Learning Model, Learning Difficulties.

Copyright (c) 2022 Fachruddiansyah Muslim, Iwan Putra, Ahmad Nasori

$\triangle$ Corresponding author

Email : fachruddiansyah.muslim@unja.ac.id

DOI https://doi.org/10.31004/edukatif.v4i1.1660

ISSN 2656-8063 (Media Cetak)

ISSN 2656-8071 (Media Online) 
Desain Pembelajaran Adaftif Berbasis Vicon melalui Model Radec bagi Peserta Didik yang Kesulitan Belajar Selama Pandemi Covid-19 - Fachruddiansyah Muslim, Iwan Putra, Ahmad Nasori

DOI: https://doi.org/10.31004/edukatif.v4i1.1660

\section{PENDAHULUAN}

Fenomena yang terjadi di Era Digital dewasa ini adalah menguatnya berbagai tuntutan penggunaan teknologi dalam menjalankan berbagai aktivitas. Fenomena tersebut semakin diperkuat dengan adanya penyebaran Virus Covid-19 yang berkepanjangan dan telah menyebabkan berbagai perubahan aktivitas serta permasalahan pada masyarakat. Penyebaran wabah Covid-19 pada skala besar di sebagian besar Negara di dunia telah menyebabkan munculnya banyak efek di semua bidang, yang paling yang penting adalah dampak Pendidikan, kesehatan, ekonomi dan sosial (A et al., 2020).

Turbelensi dalam berbagai aktivitas selama masa pandemi menyebabkan pergeseran semua kegiatan menjadi Automatisasi system terutama dalam aspek penggunaan teknologi. Perkembangan pesat ini didukung oleh berkembanganya teknologi komunikasi khususnya dalam bidang komputerisasi yang menjadikan kondisi rutinitas di abad 21 semakin otomatis. Perkembangan tersebut membuat perubahan pada segala aspek kehidupan. Begitu pula dengan pendidikan, kondisi selama masa Pandemi Covid 19 yang kompleks ini memberikan perubahan cepat pada lingkungan belajar (Batubara, 2021; Simamora, 2020; Wahid, Pribadi, Pribadi, Wakas, \& Wakas, 2020) sehingga mau tidak mau para pendidik perlu segera berbenah agar praktek pembelajaran yang dilakukannya bisa memberikan kemudahan bagi peserta didik yang mengalami kesulitan belajar selama masa pandemic. Akibat pergeseran aktivitas tersebut dalam hal pembelajaran banyak beberapa peserta didik yang mengalami kesulitan dalam mengikuti dan memahami materi pembelajaran dengan baik, salah satu diantaranya mengadopsi model pembelajaran yang mampu membantu peserta didik yang mengalami kesulitan pembelajaran selama masa pandemi.

Dampak Disaster Covid 19 telah menyebabkan berhentinya aktivitas pembelajaran yang dilakukan di Kelas, tetapi bukannya hanya dampak buruk yang ditimbulkan tetapi pandemic ini melahirkan varians inovasi terbaru serta improvasi dalam pembelajaran yang sesuai dengan peserta didik Abad 21 saat ini. Metode peer learning yang digadang-gadangkan sebagai bentuk praktek terbaik ternyata belum efektif untuk menghasilkan keterampilan dan meningkatkan kompetensi peserta didik. Peserta didik lebih butuh sesuatu yang sifatnya membentuk keterampiran seperti pemikiran kritis dan kemampuan untuk berkomunikasi yang secara efektif, berinovasi, dan menyelesaikan masalah melalui negosiasi dan kolaborasi.

Untuk itu perlu adanya revisi dan penyempurnaan masing-masing kurikulum dari aktivitas inovasi pembelajaran yang berkembang sekarang. Dimana tujuan awal dari kurikulum tidak hanya 4C tetapi lebih kompleks karena terkait aspek karakter spiritual serta karakter sosial. Agar proyeksi tersebut dapat berjalan secara maksimal perlu upaya yang terukur dan terarah melalui beberapa model pembelajaran yang inovatif yang berasal dari luar negeri seperti yang akan peneliti coba desain yang dikenal dengan nama RADEC Model (Read,Answer,Discuss, Explain, and Create).

Arah orientasi pengembangan teknologi di FKIP Universitas Jambi semakin berkembang, seiring muatan pengembangan Teknologi dan Informasi itu sendiri, hal ini ditandai dengan kemudahan dalam akses data yang sudah berbasis Big Data yang memudahkan dalam melakukan pekerjaan. Oleh karena itu dalam hal mempersiapkan generasi milleneal yang siap akan teknologi diperlukan kecakapan dan kompetensi yang sangat tinggi dan penguasaan konseptual teori yang lebih lugas (Fiction, 2010; Flatley, 2007; Fox, 1983; Monaco \& Martin, 2007) Begitu juga dengan jenjang pendidikan lainnya terutama pada jenjang Perguruan tinggi yang memerlukan beragam aspek pemberdayaan. Karena dalam tuntutuan Perkembangan Pendidik pada Abad 21 yang memerlukan kecapakan yang luas terkait pengetahuan misalnya pengetahuan akademik, penguasaaan pedagogic, social maupun budaya, selain itu diperlukan kemampuan critical thingking yang mampu tanggap dalam setiap perkembangan dan mampu mengentaskan masalah.

Imfact faktor dari perkembangan paradigm tersebut yakni diperlukan gambaran berupa bahan ajar dengan sumber yang beragam. Tetapi Fakultas Keguruan dan Ilmu Pendidikan Universitas Jambi di perhadapkan dengan permasalahan berupa pada ketersediaan bahan ajar yang minim serta terbatas 
ketersediannya. Jumlah bahan ajar Digital dan Manual Book belum up to date karena dihadapkan kendala terkait financial yang terbatas dalam penyediaan stok tersebut. Jadi Digital Book dirasa dapat menjadi pengentasan permasalahan yang selama ini dihadapi dengan kebijakan yang berorintasi pada Digitalisasi. Ketersediaan koleksi yang dikonversi dari bentuk hard copy menjadi berformat digital book melalui open acces yang telah tersedia pada ibiblio, Google Scholar dan Questia (Fichten \& Scapin, 1995; Gonzalez, 1999; Nurhayati, 2016) Kemajuan Digitalisasi Memudahkan Dalam Menciptakan Design Pembelajaran. Akhirnya penggunaan teknologi akan membantu mahasiswa yang kesulitan dan lambat dalam memahami pembelajaran terbantukan dengan kemudahan tersebut (Chen, 2010; Kevin C. Costley, 2014). Alhasil penciptaaan kondisi koginitif mahasiswa yang capak dalam Adaftif Berbasis Vicon Melalui Model Radec Berorientasi Enjiniring Bagi Peserta Didik Yang Kesulitan Belajar Selama Pandemi Covid-19. Penggunaan Vicon akan mengafirmasi kemudahan dalam proses belajar mengajar yang dilakukan oleh pendidik, hal ini ditandai dengan ketersediaan format Digital Book yang Open acces, dan mudah didapatkan dengan cepat dan informasi yang luas. Kemampuan pemahaman penggunaan format data yang terbatas menghambat dalam pemerolehan informasi yang lebih spesifik, baik dalam pengembangan aplikasi si user.

Pengembangan riset penelitian ini didasari pada studi empirical awal peneliti selama masa Pandemi COVID 19 dari bulan Maret hingga sekarang yang menemukan beragam masalah terkait dengan kurangnya kemauan mahasiswa dalam membaca buku apalagi pembelajaran tidak dilakukan secara tatap muka, sehingga harus diperlukan alternatif lain dalam menumbukan keinginan mahasiswa salah satu diantaranya dengan mengakomodasi kebutuhan belajar mahasiswa menggunakan fasilitas Vicon yang terintegrasi dengan format ePUB.

Berdasarkan studi pendahuluan yang dilakukan di lapangan sudah banyak mahasiswa di FKIP Universitas Jambi yang menggunakan Smartphone Android, dari hasil observasi diketahui mahasiswa menggunakan android mencapai $90 \%$ baik dari yang terbaru maupun keluaran lama, cukup menunjang unuk melaksanakan pembelajaran menggunakan Vicon bagi peserta didik yang lebih mudah memahami secara visual auditory. Jika dihubungkan dengan lingkup permasalahan yang telah dikemukan diatas, diperoleh bahwa proses belajar dan mengajar yang berlangsung di FKIP Universitas Jambi selama Covid-19 dirasa belum memadai. Oleh karena itu diperlukan sebuah formulasi yang dapat merangsang peserta didik melalui penggunaan bahan ajar yang lebih interaktif lagi dikelas. Dengan harapan meningkatkan hasil belajar peserta didik dengan penggunaan bahan teks ajar berbasis Vicon dapat mengatasi mahasiswa yang mengalami kesulitan dalam belajar.

Model pembelajaran RADEC dikembangkan berdasarkan beberapa hal berikut. Pertama, model ini didasarkan pada tujuan pendidikan nasional yakni untuk mengembangkan segenap potensi yang dimiliki siswa menjadi manusia yang beriman kepada Tuhan, luhur, sehat, berpengetahuan, cakap, kreatif, mandiri, dan menjadi warga negara yang demokratis serta bertanggung jawab Kedua, model ini dikembangkan atas dasar teori kontruktivisme. Vygotski mengemukakan bahwa kemampuan kognitif pada anak-anak dapat berkembang melalui interaksi dengan lingkungan sosial (Mcleod, 1978). Pada teori ini, dikenal dengan istilah Zona Pengembangan Proksimal (ZPD). Jadi dalam proses pembelajaran, ada masa dimana siswa perlu belajar secara mandiri tentang suatu konsep materi pelajaran tanpa bantuan oleh orang lain. Hal ini bertujuan untuk melihat kemampuan siswa tanpa bantuan pihak lain dan kemampuan yang hanya dapat dicapai dengan bantuan pihak lain (tingkat perkembangan potensial). Atas dasar teori tersebut, maka dalam proses pembelajaran guru harus melakukan pembelajaran diantara hal tersebut.

Design Model pembelajaran adaftif melalui RADEC memiliki beberapa futuristik dalam pembelajarannya diantaranya adalah: (1) Pada model pembelajaran adaftif Radec ini mampu menstimulis peserta didik dalam keikutsertaan terlibat pada saat proses pembelajaran berlangsung; (2) Model ini menggiring mahasiswa yang mengalami kesulitan belajar pada masa masa pandemi mampu belajar mandiri melalui automatisai penggunaan teknologi; (3) Pola pembelajaran adaptif Radec mampu mengembangkan 
pola pikir peserta didik melalui keterikan mengenai apa yang telah diketahui dengan materi yang telah diulas; (4) pembelajaran adaftif mampu memberikan korelasi mengenai pemahaman kontekstual materi yang dipelajari dengan visualisasi kehidupan nyata dari perkembangan isu kontemporer yang beredar; (5)Pembelajaran adaftif radec memberikan keleluasan kepada peserta didik dalam berperan aktif melalui bentuk keterlibatan aktif dalam berdiskusi, mengajukan pertanyaan dan dapat memberikan beberapa kesimpulan dari materi yang telah dipelajari; (6) pembelajaran Adaftif melalui Radec ini memberikan kans kepada setiap peserta didik dalam memahami konten materi pembelajaran secara mendalam dan komprehensif (H. Handayani, Sopandi, Syaodih, Suhendra, \& Hermita, 2019; Siregar, Wahyu, \& Sopandi, 2020).

Informasi yang disajikan menunjukkan bahwa dalam model pembelajaran Radec ini pada dasarnya mengembangkan potensi dan kapasitas dalam belajar yang dapat dilakukan seara mandiri melalui penguasaan pengetahuan dan keterampilan (Hany Handayani, Sopandi, Syaodih, Setiawan, \& Suhendra, 2019). Selain hal tersebut informasi yang disajikan melalui penggunaan Pembelajaran Adaftif dengan Radec menuntun peserta didik dalam berencana mengenai pengerjaan proyek yang dilakukan secara mandiri. Kegiatan yang dilakukan dalam proses pembelajaran memungkinkan peserta didik dapat melakukan aktivitas yang beragam selama proses pembelajaran serta dapat mengikutserta peserta didik dalam memilih topik yang ingin dipejari dan dari hal tersebut maka dapat dikembangkan proses keterampilan berpikir yang dapat memberikan rasa memiliki, integritas tinggi serta rasa keterlibatan dalam proses pendidikan (Setiawan, Hartati, \& Sopandi, 2020).

Bersamaan dengan hal tersebut di peroleh bahwa model pembelajaran Radec dinyatakan terbukti mampu dalam meningkatkan mengenai penguasaan konsep serta dapat mengembangkan perihal keterampilan dalam menjelaskan peserta didik Model pembelajaran adaftif mengggunakan RADEC memiliki beberapa keunggulan yang diantaranya yakni dapat menggiring peserta didik dalam meningkatkan keterampilan berpikirnya. Pada Era digital seperti sekarang ini ada beberapa keterampilan dasar yang harus dimiliki oleh setiap peserta didik yakni mengenai perihal pemahaman konseptual, berpikir kritis, kolaborasi dan komunikasi, dan berpikir kreatif (Rohmawatiningsih, Rachman, \& Yayoi, 2021).

Penerapan model pembelajaran ini di PS Pendidikan EKonomi FKIP UNJA dikarenakan kebiasan pembelajaran yang dilakukan karena pola pembelajaran setiap peserta didik disetiap daerah sehingga model pembelajaran adaftif radec ini diharapkan menjadi solusi dari permasalahan tersebut. Pembaruan yang terdapat dalam_penelitian ini ditujukan dalam mengetahui parameter ukuran penelitian tentang kesulitan belajar selama masa pandemic covid 19 terutama besaran implementatif prediktif pada penggunaan variabel Model Radec yang sebelumnya hanya diteliti pada sektor sekolah menengah atas pada pembelajaran yang berbasis konseptual. Berikutnya pembaruan (Novelty) dalam penelitian ini memperluas, mengkualifikasi atau mengelaborasi sejumlah teknik analisis yang sudah ada sebelumnya dari metode penelitian yang digunakan. Pada penelitian terdahulu kebayakan peneliti mendesign permasalahan melalui pemetaan secara kualitiatif research dan review, sedangkan pada penelitian ini mendesign model pembelajaran adaftif melalui penggunaan Vicon dalam design pembelajarannya.

Peneliti berpikir bahwa sangat diperlukan pemecahan masalah terkait hal yang telah dihdapai salah satunya yaitu melalu pengembangan bahan ajar bagi peserta didik melalui. Desain Pembelajaran Adaftif Berbasis Vicon Melalui Model RADEC bagi Peserta Didik yang Kesulitan Belajar Selama Pandemi Covid-19. Dikarenakan information sytem yang tersedia, belum memenuhi komponen dasar dalam mengembangan bahan ajar yang sesuai dengan kebutuhan peserta didik sekarang ini.

\section{METODE PENELITIAN}

Dari pemataan konsep teoritis yang telah dikemukan dapat disimpulkan kategori dari penelitian ini adalah pengembangan. Karena hal yang diperoleh berdasarkan penelitian ini berupa jenis produk yang dilakukan melalui pengembangan dan pengujian validasi dari produk yang akan diperoleh. Dimana hasil dari 
Desain pembelajaran adaftif berbasis Vicon melalui Model Radec berorientasi Enjiniring bagi peserta didik yang kesulitan belajar selama pandemi Covid-19 .

Didalam penelitian yang dilakukan digunakan beberapa pendekatan yakni kuantitatif research dengan pengembangan model yang akan digunakan berupa kerangka didalam penelitian ini yakni berupa jenis pengembangan model yang berasal dari (Borg \& Gall, 2003), melalui asimilasi model (Dick, Carey, \& Carey, 2014) dari bentuk desain model multimedia, serta model (Allesi \& Trollip, 2001) melalui penggunaan sintaks model mengembangkan dan evaluasi terkait multimedia yang terdiri dari tiga kriteria, yaitu standards, project management dan ongoing evaluation.

Hal yang dilakukan dalam penataan design video interaktif dari penelitian yang peneliti lakukan yakni melalui penyusunan kerangka dasar dalam pembelajaran yang dimuat dan diserta dengan manual book sebagai pedoman dalam perumusan produk ini nantinya yang perlu dipikirkan content isi yang dimuat dan tampilan interaktif dari multimedia ini yang ideal menurut kebutuhan peserta didik.

Ada beberapa kajian awal yang dilakukan terkait penyusunan produk yang diawali dari pengumpulan materi ajar. Proses yang dilakukan meliputi resume beberapa materi yang sesuai dengan kebutuhan peserta didik yang dirangkum pada materi pembelajaran ekonomi makro yang memuat persyaratan kelayakan Pengujian Keterandalan Pembelajaran Vicon dengan Model Read,Answer,Discuss, Explain, and Create (RADEC).

Perlu kajian efektifitas dalam mengukur pembelajaran ekonomi makro berdasarkan penilian dari Validator materi, media dari pengujian alpha, serta komentas dari user dan harapan dari pengembangan produk video interaktif berbasis

\section{HASIL PENELITIAN}

Melalui penggunaan software content management system (CMS) untuk mengembangkan media pembelajaran interaktif berbasis Vicon enjineering dengan Radec yaitu Moodle. Software Moodle yang digunakan adalah Moodle 3.0 yang dilengkapi dengan fasilitas atau fungsi video conference (BigBlueButton $B N)$. Tahap pengembangan media pembelajaran interaktif berbasis Vicon enjineering dengan Radec dilakukan melalui beberapa tahapan yaitu tahap analisis, tahap perancangan, pengembangan, implementasi dan evaluasi.

\section{Tahapan analisis (Analysis)}

Peneliti menganalisis persyaratan dengan melakukan observasi selama pembelajaran di masa pandemi Covid 19 ini di PS Pendidikan Ekonomi FKIP Universita Jambi. Kegiatan observasi dibagi menjadi dua tahap yaitu tahap pertama mengamati proses pembelajaran yang dilakukan oleh Tenaga Kependidikan pada mata beberapa mata kuliah yang bersifata saintific economic seperti pada mata kuliah ekonomi mikro, makro, ekonomi moneter, kapita selecta ekonomi, ekonomi manajerial untuk mengungkap situasi pembelajaran dan hasil kemampuan peserta didik pada semester pertama serta melakukan pengamatan melalui ketersediaan beberapa fasilitas yang mendukung proses pembelajaran. Tahap pertama observasi yang dilakukan peneliti adalah mengamati apa yang terjadi selama proses pembelajaran, apakah tenaga kependidikan menggunakan media presentasi seperti vicon dalam proses pembelajaran melalui beberapa penjelasan adaptif dari Vicon yang digunakan. Selain itu, kondisi pembelajaran dengan mengamati tenaga kependidikan dalam menjelaskan materi kepada peserta didik di PS Pendidikan Ekonomi FKIP UNJA apakah sudah menerapkan model pembelaran RADEC atau masih menggunakan cara-cara lama dengan meminta peserta didik melakukan resume pembelajaran dan berdiskusi dikelas tanpa penjelasan secara mendalam dari pengajar yang bersangkutan.

Hal ini membuat proses pengajaran menjadi tidak efisien, karena waktu yang dihabiskan hanya terbuang percuma untuk mencatat. Faktor lain yang menjadi perhatian peneliti adalah ketika terjadi kesenjangan dalam proses belajar mengajar. Hal ini menyebabkan peserta didik kurang fokus dalam 
pembelajaran dan yang lebih fatal adalah peserta didik kurang memahami apa yang disampaikan oleh tenaga Pendidikan dan mereka merasa suulit menerima informasi pembelajaran selama mas pandemic Covid 19 ini. Selain kondisi pembelajaran yang terus menerus, peneliti juga mengumpulkan data terkait nilai Peserta Didik di PS Pendidikan Ekonomi dalam satu semester melalui pelacakan Result Data di https;www.siakad.unja.ac.id.

Observasi tahap kedua yang dilakukan peneliti adalah mengamati ketersediaan fasilitas yang mendukung proses pembelajaran. Tersedianya 2 laboratorium komputerisasi, dimana 1 laboratorium memiliki 38 komputer dan 1 laboratorium memiliki 12 komputer. Pihak Civitas Akademik FKIP Universitas Jambi juga menyediakan fasilitas berupa jaringan internet atau wifi yang dapat digunakan oleh peserta didik dan tenaga kependidikan serta adanya bantuan subsidi Kuota Internet yang diberikan oleh Kemendikbud selama melaksanakan pembelajaran dirumah.

\section{Tahap Perancangan (Design)}

Tahap selanjutnya yakni dilakukan perancangan melalui pengumpulan berbagai informasi yang dibutuhkan dalam pembelajaran dan informasi penunjang lainnya dalam peranacngan Vicon berbasis Enjineering melalui pemanfaat pembelajaran menggunakan Radec berbasis Internet of thins dengan memanfaatkan fitur video conference yang tersedia pada laman https://elearning.unja.ac.id/ .

Kemudian memonitoring apakah pada saat perancangan tersebut telah dilengkapi dengan penyusunan materi, soal Latihan formatif beserta jawabannya atau soal case study melalui penggunaan perangkat gadget yang terintegrasi dan support pada media Vicon tersebut.

Berikut acitivity perancangan dari Vicon pada ILMS Unja yang dapat dijelaskan melalui Activity diagram yang menggambarkan berbagai alur aktivitas dalam sistem yang sedang dirancang, bagaimana masing- masing alir berawal dan berakhir proses. Berikut penjelasan mengenai beberapa proses aktifitas yang dirancang dalam Vicon Enjinering pada dilakukan melalui penggunaan model Radec dalam selama pembelajaran pada peserta didik yang mengalami kesulitan belajar yakni sebagai berikut:

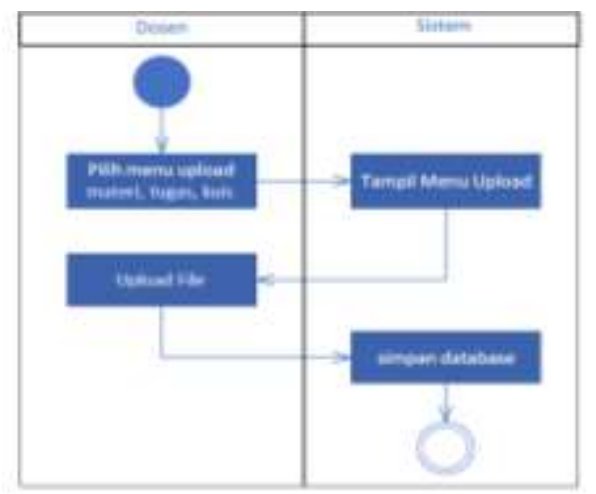

\section{Gambar 1. Activity Diagram Upload Materi, Tugas dan Kuis}

Berikutnya pada saat proses acitivity diagram akan dilihat mengenai kedalaman materi, tugas dan kuis oleh tenaga kependidikan selama melaksanakan proses pembelajaran pada PS Pendidikan Ekonomi FKIP Universitas Jambi. 


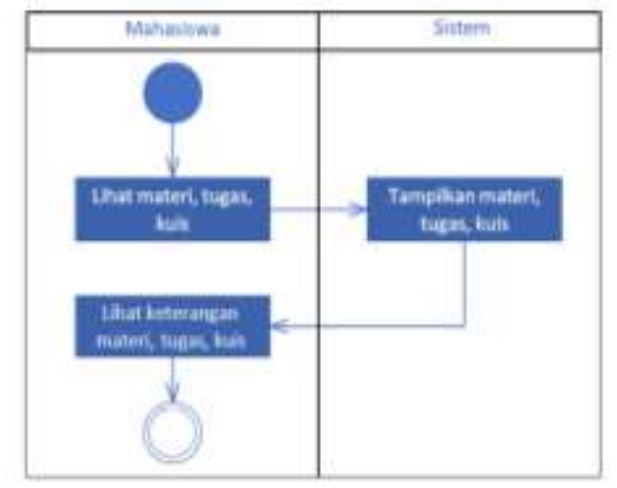

Gambar 2. Activity Diagram lihat Materi, Tugas dan Kuis Proses berikutnya adalah proses download materi, tugas, kuis.

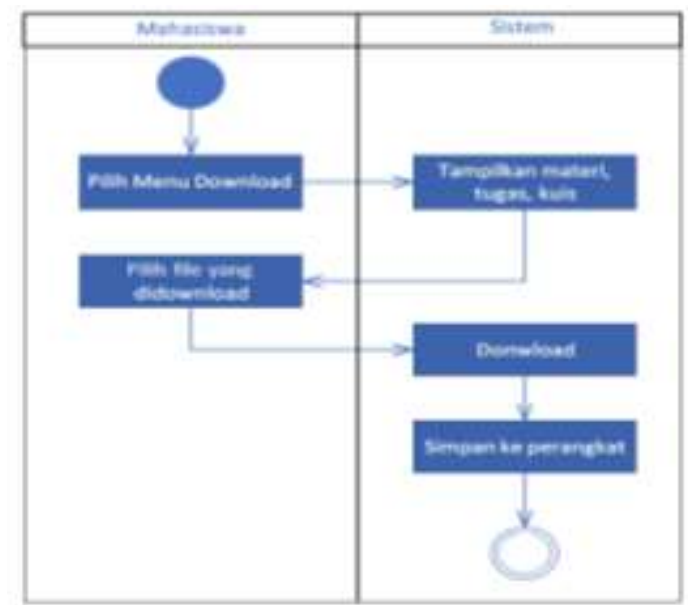

Gambar 3. Activity Diagram Download Materi, Tugas dan Kuis Berikutnya activity diagram untuk proses pembuatan kelas video conferences (VC).

\section{Tahap Pengembangan (Development)}

Pada tahap pengembangan ini akan dikaji kesesuaian konteks model pembelajaran Radec berbasis enjineering melalui Vicon dengan mengembangkan media pembelajaran interaktif berbasis video conference yang sudah tersedia dan dirancanga pada story board model design media pembelajaran.

Berikutnya akan dilakukan tahapan instalasi perangkat pada peserta didik dan tenaga kependidikan dengan beberapa software pendukung diantaranya adalah XAMPP. XAMPP merupakan server local yang dikembangkan di Universitas Jambi dalam menjalankan aktifitas pembelajaran selama masa pandemic covid 19 dengan membuat kumpulan tag database moodle pada server lokal (XAMPP). Aplikasi yang dikembankan tersebut dapat digunakan dan diunduh oleh peserta didik di lingkungan FKIP Universitas Jambi khususnya dalam membantu proses pembelajaran selama pandemic covid 19 terhadap peserta didik yang mengalami kesulitan belajar. Ketika telah dilakukan instalasi pada perangkat peserta didik dapat melakukan customize baik profil, tema, user, maupun membuat kursus atau materi yang akan disajikan.

\section{Validasi Media}

Untuk melihat keamdalan dan kelayakan media yang dikembangkan maka perlu dilakukan validasi terkai desain vicon enjineering berbasis Radec yang akan dikembangkan bagi peserta didik yang mengalami kesulitan belajar selama masa pandemic covid 19. Hal ini dilakukan dikarenaka validasi suatu media ialahpersyaratan yang mutlak bagi rancangan pengembangan sebelum memasuki tahapan ujicoba produk. 
Validasi yang dilakukan terkait kegiatan evaluasi formatif. Adapun kategori kevalidan pada penelitian ini dilihat dari validasi yang dilakukan oleh ahli media yang berasal dari Ps Pendidikan Bahasa Inggris dan PPKN dan merupakan konseptor media pada prodi tersebut yakni Doni Efriza, M.Pd dan Heri Usmanto,M.Pd dengan cara validasi butir soal dan validasi produk media pembelajaran. Adapun yang menjadi aspek dan kriteria penilaian media, yaitu aspek kemenarikan, aspek penggunaan kata dan bahasa, aspek tampilan di layar, aspek perintah, dan aspek desain tampilan. Validasi dilakukan dengan cara membubuhkan tanda checklist $(\sqrt{ })$ pada angket validasi media serta validasi produk media yang dibuat. Adapun hasil penilaian validator dapat dilihat pada Tabel 1 yang akan dikembangkan sebagai berikut:

Tabel 1 Validasi Ahli Media

\begin{tabular}{|c|c|c|c|}
\hline No & Aspek/Indikator & $\begin{array}{l}\text { Rerata/ } \\
\text { Skor }\end{array}$ & Kategori \\
\hline 1. & Kombinasi warna menarik & 3,5 & Valid \\
\hline 2. & Warna tidak mengganggu materi & 3 & Valid \\
\hline 3. & Kesesuaian tulisan dan background & 3,5 & Valid \\
\hline 4. & Ketepatan pemilihan jenis huruf & 4 & Sangat Valid \\
\hline 5. & Ketepatan pemilihan ukuran huruf & 4 & Sangat Valid \\
\hline 6. & Kejelasan gambar dan video & 3 & Valid \\
\hline 7. & $\begin{array}{lll}\text { Menggunakan Bahasa } & \text { Indonesia yang } \\
\text { sesuai dengan } & \text { Ejaan } & \text { Yang } \\
\text { Disempurnakan (EYD) } & & \end{array}$ & 4 & Sangat Valid \\
\hline 8. & $\begin{array}{lll}\begin{array}{l}\text { Bahasa yang digunakan mudah } \\
\text { dipahami }\end{array} & & \\
\end{array}$ & 4 & Sangat Valid \\
\hline 9. & Kata yang digunakan konsisten & 3 & Valid \\
\hline 10. & Tata letak tiap halaman seimbang & 3 & Valid \\
\hline 11. & $\begin{array}{l}\text { Tipe huruf yang digunakan terlihat jelas } \\
\text { dan dapat terbaca }\end{array}$ & 3 & Valid \\
\hline 12. & $\begin{array}{l}\text { Kesesuaian warna tampilan dan } \\
\text { background }\end{array}$ & 3 & Valid \\
\hline 13. & $\begin{array}{l}\text { Perintah dalam program bersifat } \\
\text { sederhana dan mudah dimengerti }\end{array}$ & 3,5 & Valid \\
\hline 14. & $\begin{array}{l}\text { Menu dan tombol dapat digunakan } \\
\text { secara mudah dan efektif }\end{array}$ & 3,5 & Valid \\
\hline 15. & $\begin{array}{l}\text { Kemudahan mengoperasikan media } \\
\text { pembelajaran }\end{array}$ & 3 & Valid \\
\hline 16. & $\begin{array}{l}\text { Tidak terjadi error pada tombol menu } \\
\text { dan navigasi }\end{array}$ & 3,5 & Valid \\
\hline 17. & Tersedianya fitur aplikasi yang jelas & 3,5 & Valid \\
\hline 18. & $\begin{array}{l}\text { Setiap bagian terhubung dengan baik } \\
\text { sehingga program tampak jelas }\end{array}$ & 3 & Valid \\
\hline 19. & $\begin{array}{l}\text { Program dapat dibuka dan ditutup } \\
\text { dengan mudah }\end{array}$ & 3 & Valid \\
\hline \multicolumn{2}{|r|}{ Rerata } & 3,37 & Valid \\
\hline
\end{tabular}

Hasil penilaian yang dilakukan validator media, diperoleh hasil perhitungan yakni bahwa nilai rata-rata total skor media sebesar 3,37 ini menandakan bahwa secara umum media pembelajaran interaktif berbasis vicon yang dikembangkan dalam mengatasi kesulitan belajar selama masa pandemic Covid 19 di lingkungan PS Pendidikan Ekonomi FKIP UNJA termasuk dalam kategori valid dan layak sehingga dinyatakan bisa digunakan pada ujicoba dalam proses pembelajaran.

\section{Tahap Implementasi (Implementation)}

Bentuk kegiatan tahapan impelementasi yang peneliti lakukan dalam mendukung proses pembelajaran pada peserta didik yang mengalami kesulitan belajar yakni dengan melakukan uji coba pada penggunaan media pembelajaran interaktif berbasis Vicon pada setiap peserta didik dan tenaga pendidik yang memanfaatkan fasilitas yang dikembangkan tersebut.

Setelah kegiatan pada proses uji coba telah dilakukan setiap pengguna diminta untuk mengisi angket feedback mengenai keterlaksanaan dan pencapaian dari pemanfaatan pengembangan media tersebut, apalagi sekarang PS Pendidikan Ekonomi telah mengadapsi Kurikulum berbasis MBKM untuk diberikan penilaian. Untuk kesempurnaan tahap implementasi yang dilakukan, peneliti juga melakukan sintesis pengamatan pada setiap aktifitas tenaga kependidikan dengan mengamati kondisi pembelajaran dengan menggunakan media 
pembelajaran interaktif berbasis vicon enjineering melalui penggunaan Radec. Untuk memberikan gambaran secara efektif pada tahap implementasi maka dilakukan pengukuran melalui uji kepraktisan dan keefektifan penggunaannya .

\section{Kepraktisan}

Kepraktisan dilakukan terkait kegiatan evaluasi formatif yang dilaksanakan di tahapan pengembangan. Aspek yang menjadi penilaian kepraktisan media dalam instrumen penilaian tenaga kependidikan adalah aspek pembelajaran, aspek penggunaan bahasa, dan aspek media. Aspek yang digunakan dalam instrumen penilaian siswa yaitu tampilan isi materi, aspek penggunaan kata dan bahasa, dan aspek penggunaan media. Hasil penilaian dapat dilihat pada Tabel 2 untuk respon tenaga kependidikan dan peserta didik sebagai berikut:

Tabel 2 Penilaian Respon Tenaga Kependidikan

\begin{tabular}{|c|l|c|c|}
\hline No & \multicolumn{1}{|c|}{ Aspek/Indikator } & $\begin{array}{c}\text { Rerata/ } \\
\text { Skor }\end{array}$ & Kategori \\
\hline 1. & Kesesuaian materi dengan Kompetensi Inti & 4 & Sangat Praktis \\
\hline 2. & $\begin{array}{l}\text { Kesesuaian materi dengan Kompetensi } \\
\text { dasar }\end{array}$ & 4 & Sangat Praktis \\
\hline 3. & Kesesuaian tujuan dengan kompetensi dasar & 4 & Sangat Praktis \\
\hline 4. & Pemberian motivasi & 3 & Praktis \\
\hline 5. & Ketersediaan rangkuman materi & 3 & Praktis \\
\hline 6. & $\begin{array}{l}\text { Kesesuaian indikator dengan Kompetensi } \\
\text { Inti }\end{array}$ & 3 & Praktis \\
\hline 7. & $\begin{array}{l}\text { Kesesuaian gambar untuk memperjelas } \\
\text { materi }\end{array}$ & 4 & Sangat Praktis \\
\hline 8. & Kesesuaian video untuk memperjelas materi & 3 & Praktis \\
\hline 9. & $\begin{array}{l}\text { Kesesuaian animasi untuk memperjelas } \\
\text { materi }\end{array}$ & 3 & Praktis \\
\hline 10. & Kesesuaian soal dengan materi & 4 & Sangat Praktis \\
\hline 11. & Penyajian materi terurut dan sistematis & 4 & Sangat Praktis \\
\hline 12. & Penggunaan bahasa yang mudah dimengerti & 4 & Sangat Praktis \\
\hline 13. & Penggunaan bahasa yang baku & 3 & Praktis \\
\hline 14. & Penggunaan bahasa yang komunikatif & 4 & Sangat Praktis \\
\hline 15. & $\begin{array}{l}\text { Kemudahan dalam menggunakan Media } \\
\text { pembelajaran interaktif produktif TKJ }\end{array}$ & 4 & Sangat Praktis \\
\hline 16. & Kejelasan petunjuk penggunaan media & 4 & Sangat Praktis \\
\hline 17. & $\begin{array}{l}\text { Tingkat interaktif peserta didik dengan } \\
\text { media }\end{array}$ & 4 & Sangat Praktis \\
\hline 18. & $\begin{array}{l}\text { Media dapat digunakan sebagai alternatif } \\
\text { belajar di luar kelas }\end{array}$ & 4 & Sangat Praktis \\
\hline & \multicolumn{1}{|c|}{ Rerata } & Sangat Praktis \\
\hline
\end{tabular}

Berdasarkan rekapitulasi penilaian mengenao respon tenaga kependidikan, di dapat informasi bahwa nilai rata-rata total skor media pembelajaran interaktif menggunakan vicon berbasis enjineering dengan ratarata penilaian sebesar 3,67 yang bermakna bahwa secara umum media pembelajaran berbasis vicon tersebut telah termasuk dalam kategori sangat praktis dan bisa digunakan dalam membantu mengatasi kesulitan selama pembelajaran dimasa Pandemi Covid 19 pada PS Pendidikan Ekonomi FKIP UNJA.

Selain penilaian mengenai respon tenaga kependidikan juga dilakukan penilaian mengenai respon peserta didik yang melakukan proses pembelajaran dirumah dengan memanfaatkan dan menggunakn teknologi dalam membantu dan penunjang proses PBM. Berikut diperoleh hasil penilaian dari peserta didik mengenai design media vicon berbasis enjineering yang dikembangkan yakni sebagai berikut: 
Tabel 3. Penilaian Respon Peserta Didik

\begin{tabular}{|c|c|c|c|}
\hline No & Aspek/Indikator & $\begin{array}{c}\text { Rerata/ } \\
\text { Skor }\end{array}$ & Kategori \\
\hline 1. & Kejelasan tampilan gambar dan animasi & 3,75 & Sangat Praktis \\
\hline 2. & Kejelasan tampilan video dan suara & 3,65 & Sangat Praktis \\
\hline 3. & $\begin{array}{l}\text { Kombinasi warna background yang } \\
\text { bervariasi }\end{array}$ & 3,5 & Sangat Praktis \\
\hline 4. & $\begin{array}{l}\text { Tipe huruf yang digunakan terlihat jelas dan } \\
\text { mudah terbaca }\end{array}$ & 3,3 & Praktis \\
\hline 5. & Kesesuaian video dengan materi ajar & 3,7 & Sangat Praktis \\
\hline 6. & $\begin{array}{l}\text { Kesesuaian gambar yang ditampilkan } \\
\text { dengan materi ajar }\end{array}$ & 3,4 & Praktis \\
\hline 7. & $\begin{array}{l}\text { Penyajian materi yang bervariasi dan } \\
\text { menarik }\end{array}$ & 3,4 & Praktis \\
\hline 8. & $\begin{array}{l}\text { Adanya tombol navigasi pada media } \\
\text { pembelajaran }\end{array}$ & 3,4 & Praktis \\
\hline 9. & Isi materi disajikan secara terurut & 3,45 & Praktis \\
\hline 10. & $\begin{array}{l}\text { Materi yang disajikan dilengkapi dengan } \\
\text { contoh soal }\end{array}$ & 3,55 & Sangat Praktis \\
\hline 11. & Petunjuk soal mudah dipahami & 3,65 & Sangat Praktis \\
\hline 12. & $\begin{array}{l}\text { Menggunakan bahasa Indonesia yang sesuai } \\
\text { dengan Ejaan Yang Disempurnakan (EYD) }\end{array}$ & 3,35 & Praktis \\
\hline 13. & Bahasa yang digunakan mudah dipahami & 3,35 & Praktis \\
\hline 14. & Kata yang digunakan konsisten & 3,55 & Sangat Praktis \\
\hline 15. & $\begin{array}{l}\text { Media pembelajaran interaktif dapat } \\
\text { digunakan dimana saja }\end{array}$ & 3,65 & Sangat Praktis \\
\hline 16. & Dilengkapi petunjuk penggunaan media & 3,45 & Praktis \\
\hline \multicolumn{2}{|r|}{ Rerata } & 3,51 & Sangat Praktis \\
\hline
\end{tabular}

Berdasarkan data pada tabel penilaian respon peserta didik, yakni diperoleh penilaian bahwa nilai ratarata total skor media pembelajaran interaktif berbasis vicon yang didesain yakni sebesar 3,51 yang bermakna bahwa secara umum media pembelajaran berbasis vicon berbasis enjinering termasuk dalam kategori sangat praktis selama digunakan dalam membantu peserta didik yang mengalami kesulitas belajar selama mengikuti pembelajaran dari rumah.

\section{Keefektifan}

Keefektifan dilakukan terkait kegiatan evaluasi formatif. Evaluasi yang dilakukan di tahapan pengembangan adalah untuk mengukur tingkat kelayakan dan keefektifan suatu media dengan menggunakan lembar penilaian aktivitas tenaga kependidikan. Adapun aspek penilaian aktivitas tenaga kependidikan dapat dilihat pada Tabel 4. sebagai berikut:

Tabel 4 Penilaian Aktivitas Tenaga Kependidikan

\begin{tabular}{|c|c|c|c|}
\hline No & Aspek/Indikator & $\begin{array}{l}\text { Rerata/ } \\
\text { Skor }\end{array}$ & Kategori \\
\hline 1. & $\begin{array}{l}\text { Menyampaikan gambaran singkat tentang } \\
\text { media pembelajaran berbasis web yang akan } \\
\text { digunakan }\end{array}$ & 3 & Efektif \\
\hline 2. & $\begin{array}{l}\text { Menyampaikan cara penggunaan media } \\
\text { pembelajaran interaktif berbasis web }\end{array}$ & 4 & Sangat Efektif \\
\hline 3. & $\begin{array}{l}\text { Memperlihatkan tombol menu dan fitur } \\
\text { yang ada pada media pembelajaran }\end{array}$ & 4 & Sangat Efektif \\
\hline 4. & $\begin{array}{l}\text { Menyebutkan materi-materi yang ada pada } \\
\text { media pembelajaran }\end{array}$ & 4 & Sangat Efektif \\
\hline 5. & Menyampaikan tujuan pembelajaran & 4 & Sangat Efektif \\
\hline 6. & $\begin{array}{l}\text { Menyampaikan hasil yang ingin dicapai } \\
\text { pada proses pembelajaran }\end{array}$ & 3 & Efektif \\
\hline 7. & Menjelaskan materi yang akan dipelajari & 4 & Sangat Efektif \\
\hline 8. & $\begin{array}{l}\text { Memperlihatkan animasi/simulasi materi } \\
\text { yang ada di media pembelajaran }\end{array}$ & 4 & Sangat Efektif \\
\hline 9. & $\begin{array}{l}\text { Membuka diskusi melalui media } \\
\text { pembelajaran }\end{array}$ & 4 & Sangat Efektif \\
\hline 10. & Membimbing/mengarahkan siswa & 3 & Efektif \\
\hline 11. & $\begin{array}{l}\text { Memberikan umpan balik/feedback terhadap } \\
\text { materi yang diperlihatkan di media } \\
\text { pembelajaran. }\end{array}$ & 3 & Efektif \\
\hline 12. & $\begin{array}{l}\text { Memberikan } \\
\text { pembelajaran }\end{array}$ tugas melalui media & 4 & Sangat Efektif \\
\hline & Rerata & 3,67 & Sangat Efektif \\
\hline
\end{tabular}




\section{KESIMPULAN}

Model Perancangan dan Pengujian Keterandalan Pembelajaran Vicon dengan Model Read, Answer, Discuss, Explain, and Create (RADEC) pada Program Studi pada dasarnya dikembangkan dengan mengadaptasi kebijakan MBKM mencakup perencanaan, proses pembelajaran, penilaian, dan evaluasi pembelajaran. Pelayanan pemenuhan masa dan beban belajar sebagai hak belajar mahasiswa melalui integrasi media dan kurikulum selama pembelajaran berlangsung dalam membantu mahasiswa yang mengalami kesulitan belajar selama masa pandemic Covid 19. Pembelajaran dilakukan Melalui penggunaan software content management system (CMS) untuk mengembangkan media pembelajaran interaktif berbasis Vicon enjineering dengan Radec yaitu Moodle. Software Moodle yang digunakan adalah Moodle 3.0 yang dilengkapi dengan fasilitas atau fungsi video conference (BigBlueButton BN).

Berdasarkan hasil penelitian, diperoleh Keefektifan berdasarkan hasil observasi aktivitas tenaga kependidikan terhadap penggunaan media pembelajaran, dimana rata-rata penilaian aktivitas tenaga kependidikan terhadap penggunaan media berada pada kategori sangat efektif. Kemudian nilai rata-rata total skor media pembelajaran interaktif yang didesign yang digunakan peserta didik selama masa pandemic Covid 19 yakni sebesar 3,67 yang bermakna bahwa secara umum media pembelajaran berbasis vicon melalui Model Radec termasuk dalam kategori sangat efektif. Berdasarkan hasil penelitian dan pembahasan yang telah diuraikan, maka dapat ditarik suatu kesimpulan bahwa media pembelajaran berbasis vicon melalui Model Radec termasuk dalam kategori sangat efektifdalam membantu peserta didik yang mengalami kesulitan belajar. Hal ini seusia dengan penelitian (Hany Handayani, Sopandi, Syaodih, Setiawan, \& Suhendra, 2019) bahwa dalam model pembelajaran Radec ini pada dasarnya dapat mengembangkan potensi dan kapasitas dalam belajar yang dapat dilakukan secara mandiri melalui penguasaan pengetahuan dan keterampilan.

Dalam penelitian ini baru sekedar mengembangkan media pembelajaran melalui model Radec pada 1 kelas dalam tingkatan universitas, belum dilakukan dan di ujicobakan pada kelas yang lain dan untuk peneliti lain bisa dilakukan dengan jenis penelitian eksperimen. Diharapkan dengan adanya hasil penelitian ini membantu para peneliti dan khususnya pendidik untuk menerapkan media pembelajaran melaui model Radec tersebut untuk membantu peserta didik yang mengalami kesulitan belajar dimasa pandemi covid 19.

\section{DAFTAR PUSTAKA}

A, J. C., B, K. B., C, J. R., D, B. M., E, M. G., G, P. A. M., \& H, S. L. (2020). Journal Of Applied Learning \& Teaching Covid-19: 20 Countries ' Higher Education Intra-Period Digital Pedagogy Responses. Journal Of Applied Learning \& Teaching, 3(1).

Allesi, S. M., \& Trollip, S. R. (2001). Multimedia For Learning: Methods And Development. Retrieved From Https://Csuglobal.Blackboard.Com/Bbcswebdav/Institution/Fcc

Content/Csfiles/Home_Dir/Externalfiles_20130401041211/Library_Xid-1005_5/Textbook

Reserve_Xid-13309_5/Ot1__Xid-14610_5/Ot1543_Xid-17718_5/Ot1543_Module2__Xid-14582_52.Pdf

Batubara, B. M. (2021). The Problems Of The World Of Education In The Middle Of The Covid-19 Pandemic. Budapest International Research And Critics Institute (Birci-Journal): Humanities And Social Sciences, 4(1), 450-457. Https://Doi.Org/10.33258/Birci.V4i1.1626

Borg, W. R., \& Gall, M. D. (2003). Educational Research An Introduction (7th Edition) By Meredith D. Gall, Walter R. Borg, Joyce P. Gall (Z-Lib.Org).Pdf (P. 683). P. 683.

Chen, R. J. (2010). Investigating Models For Preservice Teachers' Use Of Technology To Support StudentCentered Learning. Computers And Education, 55(1), 32-42. Https://Doi.Org/10.1016/J.Compedu.2009.11.015

Dick, W., Carey, L., \& Carey, J. O. (2014). Pearson New International Edition The Systematic Design Of 


\section{Instruction.}

Fichten, C. S., \& Scapin, R. (1995). Digital Technology, Learning , And Postsecondary Students With Disabilities: Where We 'Ve Been And Where We 'Re Going. 27(4), 369-379.

Fiction, U. (2010). Critical Readings: African American Girls. Journal Of Adolescent \& Adult Literacy, 53(April), 565-574. Https://Doi.Org/10.1598/Ja

Flatley, M. E. (2007). Teaching The Virtual Presentation. Business Communication Quarterly, 70(3), 301305. Https://Doi.Org/10.1177/1080569907305305

Fox, D. (1983). Personal Theories Of Teaching. Studies In Higher Education, 8(2), 151-163. Https://Doi.Org/10.1080/03075078312331379014

Gonzalez, J. F. (1999). How To Assess Memory Loss In The Elderly. Patient Care, 33(5), 197-211.

Handayani, H., Sopandi, W., Syaodih, E., Suhendra, I., \& Hermita, N. (2019). Radec: An Alternative Learning Of Higher Order Thinking Skills (Hots) Students Of Elementary School On Water Cycle. Journal Of Physics: Conference Series, 1351(1). Https://Doi.Org/10.1088/1742-6596/1351/1/012074

Handayani, Hany, Sopandi, W., Syaodih, E., Setiawan, D., \& Suhendra, I. (2019). Dampak Perlakuan Model Pembelajaran Radec Bagi Calon Guru Terhadap Kemampuan Merencanakan Pembelajaran Di Sekolah Dasar. Pendas : Jurnal Ilmiah Pendidikan Dasar, Iv, 79-93. Https://Doi.Org/10.23969/Jp.V4i1.1857

Kevin C. Costley, P. . (2014). The Positive Effects Of Technology On Teaching And Student Learning. 1-11. Retrieved From Https://Hsgm.Saglik.Gov.Tr/Depo/Birimler/Saglikli-Beslenme-Hareketli-Hayat$\mathrm{Db} /$ Yayinlar/Kitaplar/Diger-Kitaplar/Tbsa-Beslenme-Yayini.Pdf

Mcleod, S. (1978). Lev Vygotsky Culture. (1934), 1-7.

Monaco, M., \& Martin, M. (2007). The Millennial Student: A New Generation Of Learners. Athletic Training Education Journal, 2(2), 42-46. Https://Doi.Org/10.4085/1947-380x-2.2.42

Nurhayati, A. S. (2016). Peran Media Jejaring Sosial Dalam Pembelajaran Abad 21. Prosiding Temu Ilmiah Nasional Guru, 1-9(November), 632-641.

Rohmawatiningsih, W., Rachman, I., \& Yayoi, K. (2021). The Implementation Of Radec Learning Model In Thematic Learning To Increase The Concept Understanding Of Electrical Phenomenon. Momentum: Physics Education Journal, 5(2), 121-131. Https://Doi.Org/10.21067/Mpej.V5i2.5412

Setiawan, D., Hartati, T., \& Sopandi, W. (2020). Effectiveness Of Critical Multiliteration Model With Radec Model On The Ability Of Writing Explanatory Text. Eduhumaniora | Jurnal Pendidikan Dasar Kampus Cibiru, 12(1), 1-14. Https://Doi.Org/10.17509/Eh.V12i1.17445

Simamora, R. M. (2020). The Challenges Of Online Learning During The Covid-19 Pandemic: An Essay Analysis Of Performing Arts Education Students. Studies In Learning And Teaching, 1(2), 86-103. Https://Doi.Org/10.46627/Silet.V1i2.38

Siregar, L. S., Wahyu, W., \& Sopandi, W. (2020). Polymer Learning Design Using Read, Answer, Discuss, Explain And Create (Radec) Model Based On Google Classroom To Develop Student's Mastery Of Concepts. Journal Of Physics: Conference Series, 1469(1). Https://Doi.Org/10.1088/17426596/1469/1/012078

Wahid, R., Pribadi, F., Pribadi, F., Wakas, B. E., \& Wakas, B. E. (2020). Digital Activism: Covid-19 Effects In Campus Learning. Budapest International Research And Critics In Linguistics And Education (Birle) Journal, 3(3), 1336-1342. Https://Doi.Org/10.33258/Birle.V3i3.1174 